\title{
Effect of Genotype and Periodic Pruning on Storage Root Yield and Yield Components of Some Cassava Genotypes Under Rain-Fed Conditions In Ghana
}

\author{
J. Adjebeng-Danquah ${ }^{1} \&$ O. Safo-Kantanka ${ }^{2}$ \\ ${ }^{1}$ CSIR-Savannah Agricultural Research Institute, P. O. Box TL 52, Tamale, Ghana \\ ${ }^{2}$ Formerly of Department of Crop and Soil Sciences, Faculty of Agriculture, Kwame Nkrumah University of \\ Science and Technology, KNUST, Kumasi, Ghana \\ Correspondence: J. Adjebeng-Danquah, CSIR-Savannah Agricultural Research Institute, P. O. Box TL 52, \\ Tamale, Ghana. E-mail: barchus2003@yahoo.com
}

Received: June 14, 2014 Accepted: March 5, 2015 Online Published: March 17, 2015

doi:10.5539/jps.v4n2p1 URL: http://dx.doi.org/10.5539/jps.v4n2p1

\begin{abstract}
Cassava (Manihot esculenta Crantz) is cultivated primarily for its starchy roots which provide a staple for millions of people in the tropics. The foliage contains high levels of protein which can be harvested for human and animal feed. Twenty five cassava genotypes were arranged in a randomized complete block design with three replications to investigate their tolerance to periodic pruning with respect to effect on root yield and yield components. The cassava plants were periodically pruned starting from three months after planting and at three months intervals until root harvest at 12 months after planting. Storage root yields ranged between 8.3-26.2 t/ha and 28.9-85.5 $\mathrm{t} / \mathrm{ha}$ for the pruned plants and the control respectively. The pruned plants produced average root yield of $14.7 \mathrm{t} /$ ha compared with $51.5 \mathrm{t} /$ ha from the control. Though periodic pruning resulted in significant reduction in all components measured, genetic variations were observed in the level of reduction. Observed root yield reduction ranged between 40-80\%. Five genotypes; 96/1642, Afisiafi, Esambankye, Agbelifia and Bankyehemaa, recorded storage root yield reduction of less than $50 \%$ of their respective controls. Starch content and mean storage root weight were also significantly reduced by periodic pruning. The significant genetic variations in the reduction of these traits indicated different levels of tolerance which can be exploited in further studies to identify ideal cassava genotypes for dual purpose utilization for foliage and root production.
\end{abstract}

Keywords: cassava, genotypes, periodic pruning, storage root yield, percentage yield reduction

\section{Introduction}

Breeding of cassava (Manihot esculenta Cranz) solely for root yield and its characteristics in Ghana has led to the neglect of genotypes that are good foliage producers. Though cultivation of cassava solely for foliage productivity is a common practice in Asia (Indonesia, China and Thailand) and some parts of Africa (Lockard et al., 1985; Bokanga, 1994; Limsila et al., 2007; Umuhozariho et al., 2011), the practice is not common in Ghana. Past breeding efforts have focused on developing early bulking, high storage root yield, pest and disease tolerant, low hydrocyanic acid content genotypes with good cooking quality (Annor-Frempong, 1994; Nweke et al., 1994). Boampong (2001) also stated that storage root yield and its characteristics as the most important goal of cassava breeding and ranks high in the choice of variety by farmers. Therefore agronomic practices such as foliage harvesting that will interfere with storage root yield are avoided by farmers.

Apart from the starchy storage roots, the fresh foliage is also utilized in several regions of the world for animal and human consumption (Chavez et al., 2005). Several researchers have reported the nutritive value of cassava foliage which makes it a major source of protein, minerals and vitamins in human diets in certain parts of Africa (Bokanga, 1994). The leaves which are rich in minerals and vitamins, contain $17-34 \%$ protein (dry weight basis) and are used for human consumption in certain parts of Africa (Bokanga, 1994; Kobawila et al., 2005; Adjebeng-Danquah \& Safo-Kantanka, 2013). The leaves together with the unlignified upper part of the stem constitute a very good source of protein for both human and animal consumption (Ravindran and Rajaguru, 1988; Bokanga, 1994; Limsila et al., 2007). In Rwanda, cassava leaves constitute a very important vegetable which is used in several food preparations (Umuhozariho et al., 2011). However in Ghana only the roots are of economic 
importance and was ranked number one in Ghana after the country produced over 1.45 million metric tons in 2013 with over US\$ 1.51 million in foreign exchange (FAO, 2014). The potential of the foliage has not been fully exploited due to its possible interference with root yield (Hunt et al., 1977; Fasae et al., 2009).

Tung et al. (2001) reported possible decline in storage root yield as a result of intensive pruning. This is because defoliation reduces root weight due to reduced carbohydrates synthesized per plant (Wright, 1962) and hence reduced quantity of photoassimilates available for storage. The choice of an ideal cassava variety for foliage production therefore depends on its ability to tolerate periodic pruning without a significant reduction in storage root yield. However there is scanty information on the genetic variation among different cassava cultivars in terms of tolerance to periodic pruning (Tung et al., 2001). Many factors such as the differences in maturity and plant architecture could account for this variation. Early bulking genotypes begin carbohydrate accumulation at an earlier stage than late bulking types and so they are likely to be less affected by pruning than late bulking types (Okogbenin \& Fregene, 2002).

This study sought to evaluate some advanced cassava genotypes to (1) determine the extent of variation of among cassava genotypes in terms of storage root yield following periodic pruning (2) identify cassava genotypes that show least significant reduction in storage root yield with periodic pruning for possible dual-purpose utilization and (3) determine the effect of periodic pruning on storage root yield components in cassava.

\section{Materials and Methods}

\subsection{Plant Materials}

The study was conducted using 25 cassava genotypes obtained from different sources (Table 1). They were made up of eleven elite local accessions obtained from the Wenchi Agricultural Experimental Station of the Ministry of Food and Agriculture. These materials were being screened for early maturity and cooking quality. Five of the genotypes were also advanced breeding materials obtained from the International Institute of Tropical Agriculture (IITA). Nine already released varieties were also used in the study.

Table 1. List of cassava genotypes used for the study

\begin{tabular}{cccc}
\hline Genotype & Background/origin & Genotype & Background/origin \\
\hline $96 / 0160$ & Exotic accession from IITA & DMA 004 & Elite local accession \\
$96 / 0603$ & Exotic accession from IITA. & Dokuduade & Released variety (IITA) \\
$96 / 1565$ & Exotic accession from IITA & Esambankye & Released variety(IITA) \\
$96 / 1569$ & Exotic accession from IITA & Gblemoduade & Released variety (IITA) \\
$96 / 1642$ & Exotic accession from IITA & IFAD & Released variety (local) \\
Abasafitaa & Released variety (IITA) & Kyempo & Elite local accession. \\
ADI 001 & Elite local accession. & Nkabom & Released variety (local) \\
ADI 002 & Elite local accession & TANO 001 & Elite local accession. \\
Adugyama & Elite local accession. & TANO 003 & Elite local accession. \\
Afisiafi & Released variety (IITA) & TCH 001 & Elite local accession. \\
Agbelifia & Released variety (IITA) & TCH 002 & Elite local accession. \\
AWO 001 & Elite local accession. & TCH 004 & Elite local accession. \\
Bankyehemaa & Released variety (IITA) & & \\
\hline
\end{tabular}

\subsection{Field Experiment}

The field experiment was laid out as a randomized complete block design (RCBD) experiment with three replications. The 25 cassava genotypes represented the treatments. Cuttings from the 25 cassava genotypes were planted on the flat using a spacing of $60 \mathrm{~cm} \times 60 \mathrm{~cm}$ which is considered as the optimum spacing for foliage production (Limsila et al., 2007). Each plot consisted of four rows of plants with 10 plants in a row. The plot size was thus $2.4 \mathrm{~m} \times 6 \mathrm{~m}$ resulting in a plant population of approximately 27,778 plants/ha. Cassava foliage (comprising the unlignified young stems, leaves and petioles) was hand harvested following Limsila et al. (2007). 
Foliage harvesting commenced at three months after planting and was repeated at three months' intervals with the fourth harvest coinciding with root harvest (12 MAP). At root harvest, data were collected on storage root yield ( $\mathrm{t} / \mathrm{ha})$, starch content (\%), harvest index, number of storage roots per plant, mean storage root weight $(\mathrm{g})$ and storage root dry matter (\%). The starch content of the storage roots of each genotype was determined based on the specific gravity using the Reimann scale balance method as outlined by Prammanee et al. (2010). For dry matter content determination, random samples of storage roots of each of the 25 genotypes were taken and chopped into smaller pieces. These were then mixed thoroughly after which sub samples of $100 \mathrm{~g}$ each were taken for oven drying at $80{ }^{\circ} \mathrm{C}$ for 48 hours. The dry matter content (\%) was estimated based on the final dry weight as a percentage of the initial fresh weight taken.

\subsection{Data Analysis}

The data was subjected to analysis of variance (ANOVA) for randomized complete block design (RCBD) using the GenStat Release 12.1 for windows (GenStat, 2009). Genotypes and pruning were considered as factors to assess the genotypic response to pruning. Significant differences between genotypes under pruning and no pruning were tested using their standard errors of differences. Two sample t-test was performed to compare the mean performance of all genotypes under pruning and no pruning using GenStat (GenStat, 2009).

\section{Results}

\section{1 Analysis of Variance}

Analyses of variance indicated highly significant $(\mathrm{P}<0.01)$ genotype effect for root yield $(\mathrm{t} / \mathrm{ha})$ and mean root weight $(\mathrm{g})$ and very highly significant $(\mathrm{P}<0.001)$ genotype effect for starch content and storage root dry matter content (Table 2). The effect of pruning on all traits was also very highly significant $(\mathrm{P}<0.001)$. However the interaction between genotype and pruning effect on all traits were not significant $(\mathrm{P}>0.05)$.

Table 2. Mean squares for root yield and yield components of 25 cassava genotypes under pruning and no pruning

\begin{tabular}{|c|c|c|c|c|c|c|}
\hline Source of variation & D.f. & $\begin{array}{l}\text { Root yield } \\
(\mathrm{t} / \mathrm{ha})\end{array}$ & $\begin{array}{l}\text { Mean root weight } \\
\text { (g) }\end{array}$ & $\begin{array}{l}\text { Starch content } \\
(\%)\end{array}$ & Harvest index & $\begin{array}{l}\text { Dry matter content } \\
(\%)\end{array}$ \\
\hline Rep & 2 & 1877.70 & 0.08 & 2.76 & 0.081 & 3.12 \\
\hline Genotypes (G) & 24 & $453.80 * *$ & $0.02 * *$ & $25.37 * * *$ & $0.034 * * *$ & $36.75 * * *$ \\
\hline Pruning (P) & 1 & $45197.10^{* * *}$ & $2.66^{* * *}$ & $272.57 * * *$ & $1.193 * * *$ & $219.13 * * *$ \\
\hline GxP & 24 & $263.40 \mathrm{NS}$ & $0.12 \mathrm{NS}$ & $2.72 \mathrm{NS}$ & $0.010 \mathrm{NS}$ & $3.65 \mathrm{NS}$ \\
\hline Residual & 98 & 231.10 & 0.11 & 3.03 & 0.009 & 5.73 \\
\hline Total & 149 & & & & & \\
\hline
\end{tabular}

$* *, * * *=$ significant at $\mathrm{P}<0.01$, and $\mathrm{P}<0.001$ respectively. $\mathrm{NS}=$ Not significant $(\mathrm{P}>0.05)$.

\subsection{Root Yield}

Storage root yield was generally reduced when the plants were pruned as compared with the control (Table 3). Significant differences $(\mathrm{P} \leq 0.05)$ were established between the different genotypes in terms of this reduction. The pruned plants gave an average storage root yield of $14.7 \mathrm{t} / \mathrm{ha}$ as against $51.5 \mathrm{t} / \mathrm{ha}$ from the control. The reaction of the genotypes to the periodic pruning as given by their yield relative to their control could be grouped into classes of 10-20, 20-30, 30-40 up to 80-90 t/ha. Storage root yield from the pruned plants fell within the lower classes (Figure 1). Genotypes like TANO 003, DMA 004 and TCH 002 all had root yields below $10 \mathrm{t} / \mathrm{ha}$. Most of the pruned plants recorded storage root yields that fell within the 10-20 t/ha and included 96/1565, Dokuduade, Agbelifia, 96/0603, etc. The highest storage root yield recorded in the pruned plants fell within the 20-30 t/ha class included Afisiafi, Esambankye and 96/1642. The highest yielding genotype under pruning was 96/1642 which gave $26.2 \mathrm{t} / \mathrm{ha}$ and this was significantly different $(\mathrm{P} \leq 0.05)$ from most of the other genotypes. The storage root yields from the control plants were quite high as they ranged between 20-30 t/ha and 80-90 t/ha. Only one genotype (Bankyehemaa) from the control produced a storage root yield within the 20-30 t/ha class which was the least. Majority of the genotypes including ADI 001, 96/1642, ADI 002, etc. recorded storage root yields which fell within the 40-50 and 60-70 t/ha classes. Gblemoduade gave the highest yield of $85.5 \mathrm{t} / \mathrm{ha}$ fell in the highest class of 80-90 t/ha category. 
Storage root dry matter content $(\%)$ was also varied significantly $(\mathrm{P}<0.05)$ among the genotypes under pruning and the control (Table 3). Under pruning, dry matter content ranged between $32.1 \%$ and $41.3 \%$ for TANO 003 and IFAD respectively. The lowest storage root dry matter content from the control was obtained from 96/1565 (34.5\%) whilst IFAD had the highest dry matter content (43.3\%). Pruning resulted in significant reduction in dry matter content. Average root dry matter contents were $37.1 \%$ and $39.5 \%$ for pruned plants and the control respectively which were significantly different according to the t-test $(\mathrm{P}<0.05)$. However significant genetic variation was observed among the genotypes in the extent of reduction. The lowest reduction was recorded in 96/0160 (1.6\%) with TANO 003 having the highest reduction in dry matter content (17.2\%).

Table 3. Storage root yield and dry matter content of 25 cassava genotypes under pruning and no pruning

\begin{tabular}{|c|c|c|c|c|c|c|}
\hline \multirow[t]{2}{*}{ Genotypes } & \multicolumn{3}{|c|}{ Storage root yield (t/ha) } & \multicolumn{3}{|c|}{ Dry matter content (\%) } \\
\hline & Pruned plants & Control & $\%$ reduction & Pruned plants & Control & $\%$ reduction \\
\hline $96 / 0160$ & 12.00 & 73.51 & 80.41 & 36.20 & 36.81 & 1.60 \\
\hline $96 / 0603$ & 17.90 & 64.42 & 72.61 & 35.20 & 36.40 & 2.91 \\
\hline $96 / 1565$ & 19.80 & 70.20 & 70.10 & 32.61 & 34.51 & 5.32 \\
\hline $96 / 1569$ & 17.20 & 41.30 & 58.10 & 38.70 & 40.40 & 2.41 \\
\hline $96 / 1642$ & 26.20 & 59.02 & 50.31 & 33.90 & 37.11 & 8.52 \\
\hline Abasafitaa* & 15.40 & 41.30 & 62.80 & 38.22 & 40.21 & 4.91 \\
\hline ADI 001 & 11.20 & 56.02 & 79.30 & 39.80 & 41.70 & 4.52 \\
\hline ADI 002 & 14.90 & 55.70 & 58.60 & 38.10 & 40.30 & 5.21 \\
\hline Adugyama & 10.00 & 47.50 & 76.90 & 34.71 & 38.61 & 9.42 \\
\hline Afisiafi* & 20.90 & 52.90 & 55.51 & 36.20 & 40.71 & 10.90 \\
\hline Agbelifia* & 18.10 & 52.92 & 52.71 & 33.41 & 34.72 & 3.92 \\
\hline AWO 001 & 14.80 & 56.20 & 74.01 & 35.92 & 41.13 & 12.80 \\
\hline Bankyehemaa* & 14.60 & 28.90 & 40.10 & 38.01 & 42.31 & 10.32 \\
\hline DMA 004 & 8.30 & 37.81 & 69.71 & 38.20 & 39.82 & 3.60 \\
\hline Dokuduade* & 18.70 & 62.30 & 65.80 & 36.22 & 38.03 & 4.71 \\
\hline Esambankye* & 22.50 & 48.51 & 53.61 & 38.61 & 39.61 & 2.32 \\
\hline Gblemoduade* & 16.50 & 85.52 & 80.41 & 33.91 & 35.22 & 3.70 \\
\hline$I F A D^{*}$ & 14.40 & 45.31 & 65.61 & 41.30 & 43.31 & 4.63 \\
\hline Куетро & 8.90 & 41.90 & 78.00 & 41.22 & 41.90 & 1.71 \\
\hline Nkabom* & 11.80 & 30.81 & 63.22 & 38.70 & 40.83 & 5.12 \\
\hline TANO 001 & 12.30 & 44.71 & 70.60 & 40.51 & 41.31 & 2.03 \\
\hline TANO 003 & 9.60 & 35.01 & 51.41 & 32.22 & 38.82 & 17.22 \\
\hline ТСH 001 & 10.01 & 41.42 & 75.90 & 38.91 & 40.20 & 3.21 \\
\hline ТCH 002 & 9.60 & 71.50 & 68.62 & 40.10 & 43.31 & 7.42 \\
\hline ТСН 004 & 12.50 & 41.90 & 68.21 & 37.42 & 41.62 & 10.15 \\
\hline Mean & 14.70 & 51.46 & 65.70 & 37.13 & 39.56 & 5.94 \\
\hline SED & 3.63 & 20.44 & 13.48 & 2.11 & 1.82 & 6.16 \\
\hline $\mathrm{t}$ (cal)(means) & 12.35 & & & 3.29 & & \\
\hline $\mathrm{t}_{0.05(2), 48}$ & 2.011 & & & 2.011 & & \\
\hline
\end{tabular}

* Released varieties. 


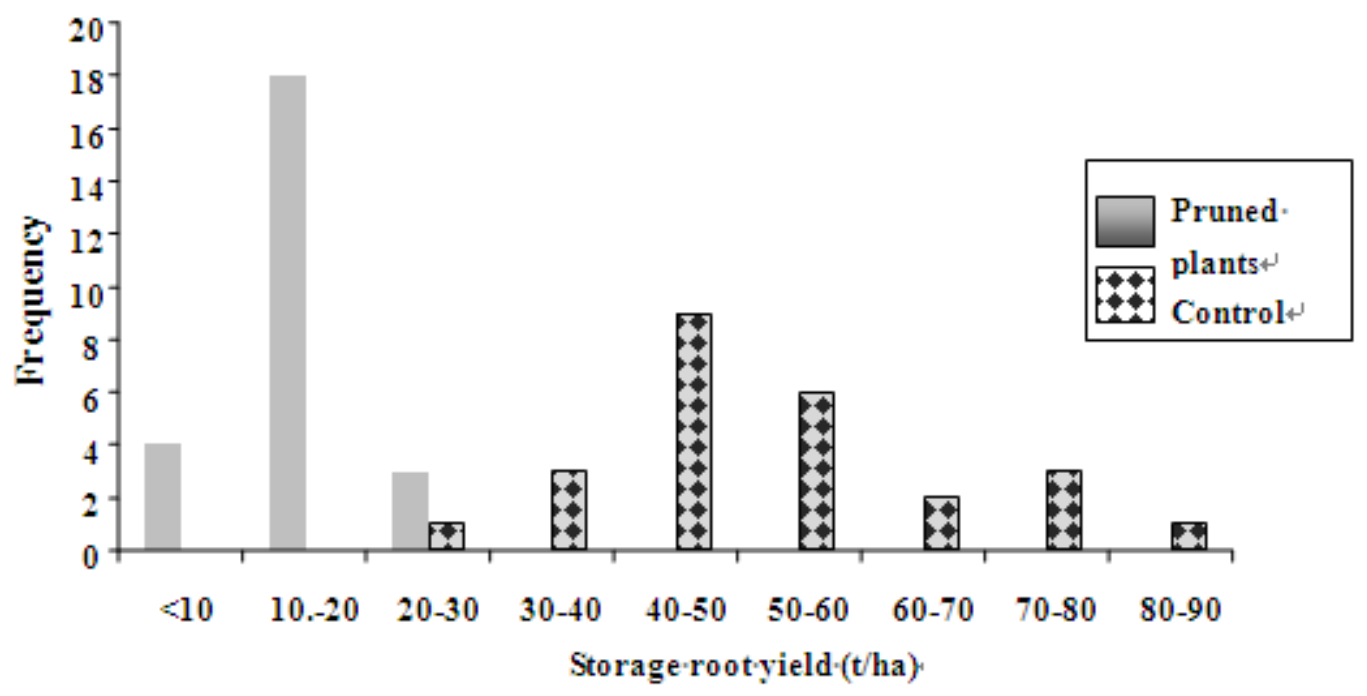

Figure 1. Range of storage root yield from the pruned plants and the control

There were also significant differences $(\mathrm{P} \leq 0.05)$ among the different genotypes in terms of storage root yield reduction as a percentage of the yield from the control plants (Table 3). The percentage (\%) reduction was also used as an index of tolerance of the different genotypes to pruning. In other words genotypes that recorded the least reduction in storage root yield were considered tolerant to pruning and as against susceptible genotypes which recorded relatively high percentage reduction. The average percentage reduction for the different genotypes which ranged between $80.4 \%$ and $40.1 \%$ can again be categorized into classes of $40-50,50-60$, up to $80-90 \%$ reduction (Figure 2). Majority (8) of the genotypes like ADI 001, Kyempo, TCH 001, TANO 001, etc. recorded reductions that fell within the $70-80 \%$ category with equal number of seven each being recorded in the $50-60$ and $60-70 \%$ categories. Only one genotype (Bankyehemaa) recorded a reduction within the $40-50 \%$ category. Two genotypes, Gblemoduade and 96/0160 suffered yield reductions which fell within the 80-90\% category.

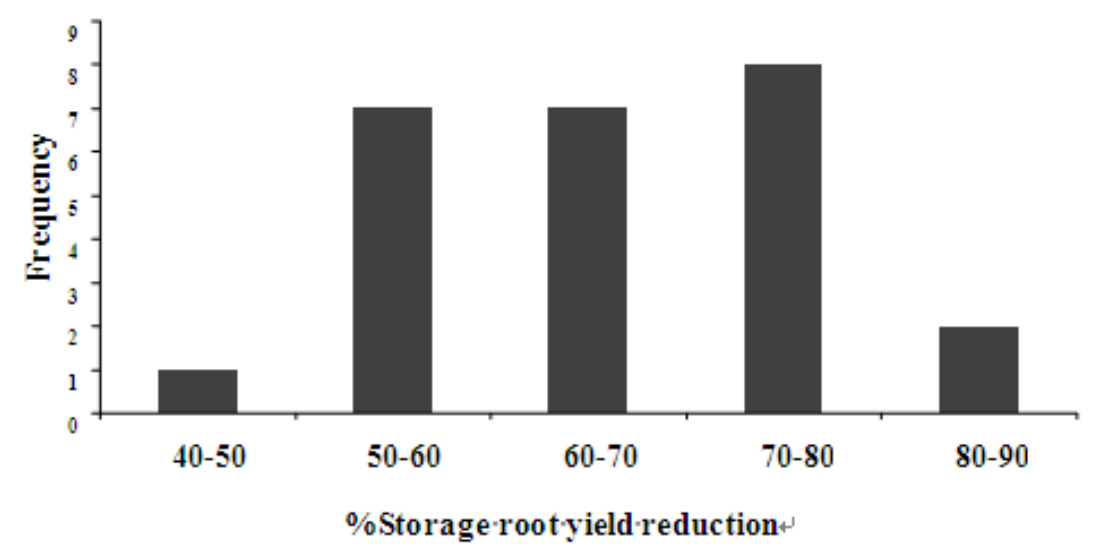

Figure 2. Frequency distribution of the range of $\%$ storage root yield reduction

\subsection{Mean Storage Root Weight and Starch Content as Affected by Pruning}

Storage root yield in cassava is determined by the number and the size of storage roots. Periodic pruning had a significant effect $(\mathrm{P} \leq 0.05)$ on mean storage root weight (Table 4$)$. Generally smaller storage roots were produced by the periodically pruned plants as compared with the control plants that produced relatively bigger 
storage roots. The average mean storage root weight of the pruned plants was $180 \mathrm{~g}$ which was significantly $(\mathrm{P} \leq$ 0.05 ) lower than those of the control plants which produced an average mean storage root weight of $450 \mathrm{~g}$. Mean storage root weights from the pruned plants ranged between $120 \mathrm{~g}$ for Kyempo and $250 \mathrm{~g}$ for 96/1642. Genotypes like AWO 001, 96/1569, IFAD, Agbelifia, Esambankye, Gblemoduade and 96/1642 all produced mean storage root weights that were above the average values recorded in the pruned plants. The mean storage root weight from the control also ranged between 290g and 600g for DMA 004 and AWO 001 respectively. Genotypic variation was observed in the reduction in mean root weight in the pruned plants compared with the control as indicated by the percentage reduction which varied from a low of $41.9 \%$ for Agbelifia and $73.4 \%$ for Kyempo (Table 4).

Pruning also had a significant effect on the starch content of the different cassava genotypes being especially higher in the control than the pruned plants (Table 4). The different genotypes however responded differently to the starch content reduction. IFAD had the highest starch content of $19.7 \%$ which was significantly different $(\mathrm{P} \leq$ 0.05) from the most of the other genotypes when pruned. The starch content was however lower than the starch content obtained from the control (22.8\%). Genotypes 96/1565 and 961642 recorded the least starch contents of $12.1 \%$ and $12.2 \%$ respectively. In the case of the control, TCH 004 recorded the highest starch content of $23.2 \%$ with 96/1565 recording the least starch content (12.7\%). Nkabom, Dokuduade, Bankyehemaa and IFAD were the released varieties that maintained relatively high starch content when pruned. Average starch content for all genotypes under pruning was also significantly lower under pruning than the control according to the two-sample t-test as well as the difference in starch contents expressed as a percentage of the control. The least percentage reduction was recorded in 96/1565 (3.0\%) with 96/1642 having the highest percentage reduction in starch content $(26.3 \%)$ in the pruned plants compared with the control. 
Table 4. Storage root yield components as affected by pruning

\begin{tabular}{|c|c|c|c|c|c|c|}
\hline \multirow{2}{*}{ Genotypes } & \multicolumn{3}{|c|}{ Mean storage root weight $(\mathrm{g})$} & \multicolumn{3}{|c|}{ Starch content $(\%)$} \\
\hline & Pruned plants & Control & $\%$ reduction & Pruned plants & Control & $\%$ reduction \\
\hline $96 / 1642$ & 250.00 & 420.00 & 42.60 & 12.20 & 16.70 & 26.30 \\
\hline Esambankye* & 240.00 & 490.00 & 43.90 & 16.70 & 20.50 & 17.60 \\
\hline Afisiafi* & 210.00 & 390.00 & 43.00 & 16.00 & 18.50 & 13.70 \\
\hline $96 / 1565$ & 140.00 & 430.00 & 64.90 & 12.10 & 12.70 & 3.00 \\
\hline Dokuduade* & 180.00 & 550.00 & 64.40 & 17.10 & 18.80 & 9.90 \\
\hline Agbelifia* & 200.00 & 380.00 & 41.90 & 14.30 & 15.10 & 5.10 \\
\hline $96 / 0603$ & 230.00 & 450.00 & 50.20 & 14.70 & 16.40 & 10.10 \\
\hline $96 / 1569$ & 200.00 & 350.00 & 42.30 & 17.20 & 20.30 & 15.00 \\
\hline Gblemoduade* $^{*}$ & 200.00 & 570.00 & 65.50 & 13.10 & 15.70 & 16.00 \\
\hline Abasafitaa* & 180.00 & 450.00 & 59.40 & 16.00 & 18.90 & 14.70 \\
\hline ADI 002 & 160.00 & 510.00 & 65.00 & 15.10 & 19.30 & 21.40 \\
\hline AWO 001 & 240.00 & 600.00 & 59.90 & 15.50 & 20.30 & 23.50 \\
\hline Bankyehemaa* & 130.00 & 290.00 & 56.20 & 16.90 & 21.10 & 20.40 \\
\hline$I F A D^{*}$ & 210.00 & 490.00 & 57.90 & 19.70 & 22.80 & 12.40 \\
\hline ТCH 004 & 150.00 & 420.00 & 62.80 & 18.00 & 23.20 & 22.30 \\
\hline TANO 001 & 150.00 & 470.00 & 65.30 & 16.90 & 19.20 & 12.40 \\
\hline $96 / 0160$ & 170.00 & 480.00 & 63.80 & 17.30 & 19.80 & 12.20 \\
\hline Nkabom* & 180.00 & 430.00 & 49.30 & 18.90 & 20.30 & 6.90 \\
\hline ADI 001 & 150.00 & 510.00 & 69.70 & 17.70 & 18.60 & 4.70 \\
\hline Adugyama & 140.00 & 410.00 & 65.20 & 14.30 & 18.80 & 23.60 \\
\hline ТCH 001 & 120.00 & 430.00 & 71.30 & 17.50 & 19.50 & 10.30 \\
\hline ТCH 002 & 140.00 & 470.00 & 52.10 & 15.30 & 17.20 & 15.90 \\
\hline TANO 003 & 160.00 & 480.00 & 64.60 & 18.20 & 21.80 & 11.30 \\
\hline Kуетро & 120.00 & 460.00 & 73.40 & 17.70 & 18.50 & 4.40 \\
\hline DMA 004 & 130.00 & 280.00 & 49.50 & 16.10 & 18.10 & 9.10 \\
\hline Mean & 180.00 & 450.00 & 57.8 & 16.20 & 18.90 & 13.70 \\
\hline SED & 41.35 & 82.20 & 11.33 & 1.52 & 1.32 & 4.21 \\
\hline t (cal)(means) & 15.99 & & & 4.40 & & \\
\hline $\mathrm{t}_{0.05(2), 48}$ & 2.011 & & & 2.011 & & \\
\hline
\end{tabular}

* Released varieties.

\subsection{Effect of Pruning on Harvest Index (HI)}

Significant differences $(\mathrm{P} \leq 0.05)$ were observed for harvest index in both the pruned and the control plants (Table 5). Genotype $96 / 1642$ recorded the highest HI of 0.54 in the pruned plants with the least being produced by TANO 003 (0.22). Generally the pruned plants produced lower HI as compared to the control. Agbelifia, Abasafitaa, 96/0160, 96/1565 and 96/0603 had quite high HI in the control plots. The comparison from the control also reveals that most of the genotypes with high $\mathrm{HI}$ in the control plants also had lower $\mathrm{HI}$ in the pruned plants except Agbelifia, Esambankye and 96/0603 which produced quite high HI both in the control and the pruned plants. Significant $(\mathrm{P} \leq 0.05)$ percentage $(\%)$ reduction in harvest index in the pruned plants relative to the control was also observed. Esambankye had the least percentage reduction in HI $(3.85 \%)$ which was significantly lower than most of the other genotypes. The highest percentage reduction was observed in Kyempo $(59.32 \%)$. 
Table 5. Harvest index (HI) from pruned plants and the control

\begin{tabular}{|c|c|c|c|}
\hline \multirow{2}{*}{ Genotypes } & \multicolumn{2}{|l|}{ Harvest index } & \multirow{2}{*}{$\%$ reduction } \\
\hline & Pruned plants & Control & \\
\hline $96 / 1569$ & 0.54 & 0.63 & 14.29 \\
\hline Agbelifia* & 0.53 & 0.68 & 22.06 \\
\hline Esambankye* & 0.50 & 0.52 & 3.85 \\
\hline $96 / 0603$ & 0.48 & 0.61 & 21.31 \\
\hline $96 / 1642$ & 0.44 & 0.51 & 13.73 \\
\hline Abasafitaa* & 0.44 & 0.68 & 35.29 \\
\hline IFAD* & 0.43 & 0.58 & 25.86 \\
\hline $96 / 1565$ & 0.42 & 0.63 & 33.33 \\
\hline Afisiafi* & 0.40 & 0.58 & 31.03 \\
\hline Nkabom* & 0.37 & 0.54 & 31.48 \\
\hline Bankyehemaa* & 0.37 & 0.39 & 5.13 \\
\hline AWO 001 & 0.36 & 0.56 & 35.71 \\
\hline Gblemoduade* & 0.35 & 0.61 & 42.62 \\
\hline ТCH 001 & 0.35 & 0.56 & 37.50 \\
\hline Adugyama & 0.34 & 0.58 & 41.38 \\
\hline $96 / 0160$ & 0.34 & 0.60 & 43.33 \\
\hline ТCH 002 & 0.34 & 0.42 & 19.05 \\
\hline Dokuduade* & 0.31 & 0.57 & 45.61 \\
\hline ADI 002 & 0.31 & 0.48 & 35.42 \\
\hline ADI 001 & 0.30 & 0.57 & 47.37 \\
\hline TANO 001 & 0.29 & 0.47 & 38.30 \\
\hline ТCH 004 & 0.27 & 0.47 & 42.55 \\
\hline DMA 004 & 0.27 & 0.45 & 40.00 \\
\hline Kуетро & 0.24 & 0.59 & 59.32 \\
\hline TANO 003 & 0.22 & 0.37 & 40.54 \\
\hline Mean & 0.37 & 0.55 & 32.53 \\
\hline SED & 0.08 & 0.07 & 14.29 \\
\hline $\mathrm{t}$ (cal)(means) & 7.37 & & \\
\hline $\mathrm{t}_{0.05(2), 48}$ & 2.011 & & \\
\hline
\end{tabular}

* Released varieties.

\section{Discussion}

\subsection{Effect of Pruning on Storage Root Yield and Dry Matter Content}

Even though periodic pruning at 2-3 month intervals have been reported to result in marginal reduction in storage root yield (Dahniya et al., 1981; Lockard et al., 1985) the results from this study suggested otherwise. Periodic pruning generally had a significant negative effect on storage root yield but there were genotypic differences in the extent of reduction. For example the reduction in yield as a percentage of the control varied from as high as $80 \%$ for Gblemoduade to as low as $40 \%$ for Bankyehemaa. Similar observed variations in cassava genotypes in terms of their ability to tolerate periodic pruning have been reported (Ravindran \& Rajaguru, 1988). Therefore careful varietal selection would be very critical in choosing cassava for foliage production. The decline in storage root yield resulting from pruning could be expected since the foliage is the 
photosynthetic apparatus and therefore responsible for photosynthesis. The foliage removal therefore led to reduction in the amount of photosynthates produced and stored in the roots. Hunt et al. (1977) asserted that deposition of starch in storage roots can be reduced if the supply from the top is interrupted as occurs when much of the leaf and stem materials are removed. Genotypic differences were however observed in the extent of reduction in root yield resulting from pruning. Many factors such as variation in maturity and plant architecture could account for these genetic differences. Early bulking genotypes begin carbohydrate accumulation at an earlier stage than late bulking types and so they are likely to be less affected by pruning than late bulking types. Okogbenin and Fregene (2002) observed that late bulking cassava genotypes have the foliage as the active growing sinks for the first seven months after planting whilst in fast or early bulking genotypes, rapid increase in storage root development occur in the first six months of growth. In this case the fast bulking genotypes might have accumulated some amount of photosynthates at the time the pruning was initiated compared with the late bulking genotypes. Another trait that could affect a variety's tolerance to pruning in terms of root yield is the plant's architecture (whether erect or profuse branching at an early stage of growth). Erect non-branching genotypes are more likely to be severely affected as compared with profuse branching genotypes owing to their rapid initial vegetative growth at the expense of storage root bulking. In a study involving two cassava varieties with different growth habits, Dahniya et al. (1981) reported a greater storage root yield reduction in an erect local cassava variety Isunikakiyan than TMS 30211, a branching type when they were both pruned. From the results of this study, it can be inferred that 96/1642, Afisiafi, Esambankye, Agbelifia and Bankyehemaa are relatively tolerant to periodic pruning as their storage root yield reduction was just around $50 \%$. Storage root dry matter content was also significantly reduced when the plants were pruned though genetic variability was observed among the genotypes in terms of the reduction. Similar declines in dry matter content among pruned plants were observed in Thailand by Chantaprasarn and Wanapat (2003) in a study involving a local cassava variety, Rayong 60. The reduction in dry matter content of the pruned plants could be attributed to the need to remobilize the stored carbohydrates for regrowth of new shoots any time the plants were pruned but this was not the case in the control plots where the foliage were left intact (Sagrilo et al., 2003). These periodic disturbances might have interfered with the accumulation of carbohydrates leading to the reduction as reported by other studies (Oliveira et al., 2010; Andrade et al., 2011). The significant genetic variation in the extent of reduction observed among the cassava genotypes provides opportunity for selection in the genetic improvement of cassava for tolerance to periodic pruning.

\subsection{Pruning and Root Yield Components}

Though periodic pruning significantly reduced the storage root yield and its components, there were differences among the different genotypes on the extent of reduction. Ayoola and Agboola (2004) observed reduction in yield and mean storage root weight when cassava plants were pruned irrespective of the pruning method. This was corroborated by the results of this study. There were however differences in the degree of reduction. The reduction in storage root sizes in the pruned plants could be explained by the fact that as the plants were pruned, photosynthates that should have been used for storage root bulking were used for regrowth of new shoots. This therefore resulted in smaller storage roots due to reduced carbohydrates available for storage root bulking possibly due to reduced carbohydrates synthesized per plant and hence reduced quantity of food available for storage (Wright, 1962).

\subsection{Starch Content and Pruning}

Pruning generally reduced the starch content of the storage roots compared to the control but there were varietal differences. For example the average starch content of the pruned plants was $16.2 \%$ compared to the $18.9 \%$ recorded by the control. Genotypes $96 / 1565$ was most affected by pruning giving a starch content of $12 \%$ compared to its corresponding starch content of $16.7 \%$ in the control. The reduction in starch content when the plants were pruned could be explained by the fact that as the plants were pruned, the stored starch was converted to sugar and translocated to the buds for regrowth. According to Mitchell (1970) carbohydrate reserves are used for regrowth of new leaves until the new leaves can photosynthesise before further starch accumulation can begin sometimes to the original level. As the supply from the top part was curtailed following the repeated pruning, deposition of starch in the roots was reduced (Hunt et al., 1977) resulting in the smaller storage roots compared with the control which was left undisturbed.

\subsection{Harvest Index}

According to Alves (2002) harvest index is a measure of dry matter distribution to the economically important part and it represents the efficiency of storage root bulking (Fregene \& Puonti-Kaerlas, 2002). Harvest index was significantly affected by pruning. This was to be expected since the top growth was periodically removed, more 
vegetative growth was promoted at the expense of root production. There were however genetic differences considering the wide range of values obtained for the different genotypes under pruning and the control. For example the harvest indices from the control plots ranged between $0.37-0.68$ as against $0.24-0.54$ for the pruned plants. Significant genetic differences in cassava genotypes in terms of the harvest index have been reported (Alves, 2002). This therefore provides opportunity for selection for high yield potential under pruning and no pruning regimes (Kawano et al., 1998).

\section{Conclusion}

Cassava research in Ghana has been based mostly on developing improved varieties that are high yielding with high dry matter and also tolerant to common diseases and pests and meet farmers' expectation. Evaluation for tolerance to periodic pruning is seldom considered. This study has opened a new chapter in the area of identifying cassava genotypes that are tolerant to periodic pruning and for that matter suitable for dual purpose production. The identification of genotypic variation in tolerance to periodic pruning will afford researchers the opportunity to explore the cassava gene pool for the ideal genotype that will produce adequate amount of foliage without significant reduction in storage root yield.

\section{Acknowledgements}

The authors are grateful to the Root and Tuber Improvement Programme for the financial assistance during the field work. Special thanks go to the cassava breeding section of the Crops Research Institute, Kumasi for providing the cassava genotypes for the work. The staffs of the Ministry of Food and Agriculture Experimental Stations at Wenchi and Mampong are also acknowledged for their assistance during the period of the experiment.

\section{References}

Adjebeng-Danquah, J., \& Safo-Kantanka, O. (2013). Genetic variation in foliage and protein yield of some elite cassava (Manihot esculenta crantz) genotypes in Ghana. J. Plant Breed. Genet, 1(2), 46-55

Alves, A. A. C. (2002). Cassava Botany and Physiology. In R. J. Hillocks, M. J. Thresh \& A. C. Bellotti (Eds.). Cassava: Biology, Production and Utilization (pp. 67-89). CABI Publishing, CAB International, Wallingford, Oxon, UK. http://dx.doi.org/10.1079/9780851995243.0067

Andrade, J. S., Viana, A. E. S., Cardoso, A. D., Matsumoto, S. N., \& Novaes, Q. S. (2011). Pruning times on cassava. Rev. Ciên. Agron., 42(3), 693-701.

Annor-Frempong, C. (1994). A survey of cassava cultivation practices in Ghana. Acta Hortic., 380, 216-221.

Ayoola, O. T., \& Agboola, A. A. (2004). Influence of cassava planting patterns and pruning methods on crop yield in a cassava-based cropping system. Afr. Crop Sci. J., 12, 115-122.

Boampong, E. (2001). Collection and characterization of local cassava germplasm from the Brong-Ahafo Region. MSc. Thesis, Department of Crop and Soil Sciences, Faculty of Agriculture, KNUST Kumasi University, Ghana.

Bokanga, M. (1994). Processing of cassava leaves for human consumption. Acta Hortic., 375, 203 -207.

Chantaprasarn, B., \& Wanapat, M. (2003). Effects of different harvest intervals on cassava foliage (cassava hay) and root yield. Tropical Feed Resources Research and Development Center (TROFREC) Department of Animal Science, Faculty of Agriculture, Khon Kaen University, Khon Kaen 40002, Thailand. Retrived from http://www.mekarn.org/msc2003-05/theses05/chan_p1.pdf

Chavez, A. L., Sanchez, T., \& Ceballos, H. (2005). Variation in quality traits in cassava roots evaluated in landraces and improved clones. Euphytica, 143, 125-133. http://dx.doi.org/10.1007/s10681-005-3057-2

Dahniya, M. T., Oputa, C. O., \& Hahn, S. K. (1981). Effects of harvesting frequency on leaf and root yields of cassava. Exp. Agric., 17, 91-95. http://dx.doi.org/10.1017/S0014479700011273

FAO. (2004). Food and agriculture organization of the United Nations Rome. FAOSTAT Database Collections.

FAO. (2014). Food and Agriculture organization of the United Nations Rome. FAOSTAT Database Collections Retrieved from http://faostat.fao.org/CountryProfiles/Country_Profile/Direct.aspx?lang=en\&area $=81$

Fasae, O. A., Adu, I. F., Aina, A. B. J., \& Elemo, K. A. (2009). Production, defoliation and storage of cassava leaves as dry Season forage for small ruminants in smallholder crop-Livestock production system. Agricultura Tropica et Subtropica, 42(1), 15-19.

Fregene, M., \& Puonti-Kaerlas, J. (2002). Cassava Biotechnology. In R. J. Hillocks, M .J. Thresh \& A. C. Bellotti (Eds.), Cassava: Biology, Production and Utilization (pp. 179-207). CABI Publishing, CAB 
International, Wallingford, Oxon, UK. http://dx.doi.org/10.1079/9780851995243.0179

GenStat. (2009). GenStat for Windows (12th ed.). Introduction. VSN International, Hemel Hempstead.

Hunt, I. A., Wholey, D. W., \& Cock, J. H. (1977). Growth physiology of cassava (Manihot esculenta Crantz). Field Crops Abst., 30, 77-91.

Kawano, K., Narintaraporn, P., Sarakarn, S., Limsila, A., Limsila, J., Suparhan, D., \& Wantananonta, W. (1998). Yield improvement in a multi-stage breeding programme for cassava. Crop Sci., 38, 325-332. http://dx.doi.org/10.2135/cropsci1998.0011183X003800020007x

Limsila, A., Tungsakul, S., Sarawat, P., Wattananonta, W., Aekmahachai, P., \& Howeler, R. H. (2007). Cassava Leaf Production Research in Thailand. In R. H. Howeler (Ed.), Cassava Research and Development in Asia: Exploring New Opportunities for an Ancient Crop. Proc. of the $7^{\text {th }}$ Regional Cassava Workshop held in Bankok, Thailand. Oct 28- Nov 1, 2002.

Lockard, R. G., Saqui, M. A., \& Wounuah, D. D. (1985). Effects of time and frequency of leaf harvest on growth and yield of cassava (Manihot esculenta Crantz) in Liberia. Field Crops Res., 12, 75-180. http://dx.doi.org/10.1016/0378-4290(85)90063-2

Mitchell, R. L. (1970). Carbohydrate, Protein and Lipid Nutrition. Crop Growth and Culture (1st ed). (Vol. 1, pp. 71-91). Chicago: Ames: Iowa State University Press.

Nweke, F. I., Dixon, A. G. O., Asiedu, R., \& Folayan, S. A. (1994). Cassava varietal needs of farmers and potential for production and growth in Africa. Collaborative Study of Cassava in Africa (COSCA). IITA, Ibadan, Working paper No. 101994.

Okogbenin, E., \& Fregene, M. (2002). Genetic analysis and QTL mapping of early root bulking in an F1 population of non-inbred parents in cassava (Manihot esculenta Crantz). Theoret. Applied Genet., 106, 58-66.

Oliveira, S. P., Viana, A. E. S., Matsumoto, S. N., Cardoso-Júnior, N. S., Sediyama, T., \& São-José, A. R. (2010). Effect of pruning and harvest time on cassava agronomic characteristics. Acta Sci. Agron., 32(1), 99-108.

Prammanee, S., Kamprerasart, K. Salakan, S., \& Sriroth, K. (2010). Growth and starch content evaluation on newly released cassava cultivars, Rayong 9 , Rayong 7 and Rayong 80 at different harvest times. Kasetsart $J$. (Nat. Sci.), 44, 558-563.

Ravindran, V., \& Rajaguru, A. S. B. (1988). Effect of stem pruning on cassava root yield and leaf growth. Sri Lankan J. Agric. Sci., 25, 32-37.

Sagrilo, E., Vidigal-Filho, O., Pequeno, M. G., Scapim, C. A., Vidigal, M .C. G., Diniz, S. P. S. S., Modesto, E. C., \& Kvutschal, M. V. (2003). Effect of harvest period on the quality of storage roots and protein content of leaves in five cassava cultivars (Manihot esculenta Crantz). Braz. Arch. Biol. Technol., 46, 295-305. http://dx.doi.org/10.1590/S1516-89132003000200022

Tung, C. M., Liang, J. B., Tan, S. L., Ong, H. K., \& Zelan, Z. A. (2001). Fodder productivity and growth persistency of three local cassava varieties. Asian-Aust. J. Anim. Sci, 14(9), 1253-1259.

Umuhozariho, M. G., Shayo, N .B. Msuy, J. M., \& Sallah, P. Y. K. (2011). Utilization of Cassava Leaves as a Vegetable in Rwanda. Rwanda Journal, 24 Series E 201.

Wright, N. (1962). Root weight and distribution of blue panic grass (Panicum anticlotale Petz) as affected by fertilization, cutting height and soil moisture stress. Agron. J., 54, 200-202. http://dx.doi.org/10.2134/agronj1962.00021962005400030006x

\section{Copyrights}

Copyright for this article is retained by the author(s), with first publication rights granted to the journal.

This is an open-access article distributed under the terms and conditions of the Creative Commons Attribution license (http://creativecommons.org/licenses/by/3.0/). 